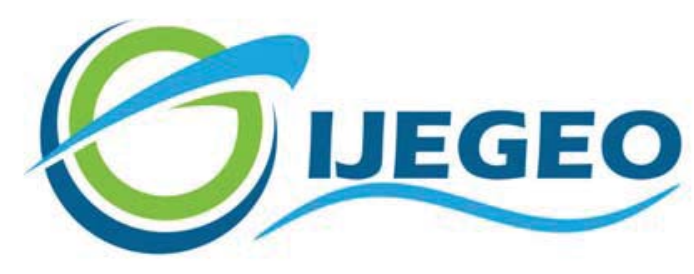

International Journal of Environment and Geoinformatics (IJEGEO) is an international, multidisciplinary, peer reviewed, open access journal.

\title{
Estimation of Actual Evapotranspiration in Panam Canal Command Using Remote Sensing and Geographical Information System (GIS)
}

\section{Sachin SUTARIYA., Ankur HIRAPARA., Mukesh K. TIWARI}

\author{
Chief in Editor \\ Prof. Dr. Cem Gazioğlu \\ Co-Editors \\ Prof. Dr. Dursun Zafer Şeker, Prof. Dr. Şinasi Kaya, \\ Prof. Dr. Ayşegül Tanık and Assist. Prof. Dr. Volkan Demir
}

Editorial Committee (June 2021)

\begin{abstract}
Assoc. Prof. Dr. Abdullah Aksu (TR), Assit. Prof. Dr. Uğur Algancı (TR), Prof. Dr. Bedri Alpar (TR), Assoc. Prof. Dr. Aslı Aslan (US), Prof. Dr. Levent Bat (TR), Prof. Dr. Paul Bates (UK), İrşad Bayırhan (TR), Prof. Dr. Bülent Bayram (TR), Prof. Dr. Luis M. Botana (ES), Prof. Dr. Nuray Çağlar (TR), Prof. Dr. Sukanta Dash (IN), Dr. Soofia T. Elias (UK), Prof. Dr. A. Evren Erginal (TR), Assoc. Prof. Dr. Cüneyt Erenoğlu (TR), Dr. Dieter Fritsch (DE), Prof. Dr. Çiğgem Göksel (TR), Prof.Dr. Lena Halounova (CZ), Prof. Dr. Manik Kalubarme (IN), Dr. Hakan Kaya (TR), Assist. Prof. Dr. Serkan Kükrer (TR), Assoc. Prof. Dr. Maged Marghany (MY), Prof. Dr. Michael Meadows (ZA), Prof. Dr. Nebiye Musaoğlu (TR), Prof. Dr. Masafumi Nakagawa (JP), Prof. Dr. Hasan Özdemir (TR), Prof. Dr. Chryssy Potsiou (GR), Prof. Dr. Erol Sarı (TR), Prof. Dr. Maria Paradiso (IT), Prof. Dr. Petros Patias (GR), Prof. Dr. Elif Sertel (TR), Prof. Dr. Nüket Sivri (TR), Prof. Dr. Füsun Balık Şanlı (TR), Prof. Dr. Uğur Şanlı (TR), Duygu Ülker (TR), Prof. Dr. Seyfettin Taş (TR), Assoc. Prof. Dr. Ömer Suat Taşkın (TR), Assist. Prof. Dr. Tuba Ünsal (TR), Dr. Manousos Valyrakis (UK), Dr. İnese Varna (LV), Dr. Petra Visser (NL), Prof. Dr. Selma Ünlü (TR), Assoc. Prof. Dr. Oral Yağcı (TR), Prof. Dr. Murat Yakar (TR), Assoc. Prof. Dr. İ. Noyan Yılmaz (AU); Assit. Prof. Dr. Sibel Zeki (TR)
\end{abstract}




\title{
Estimation of Actual Evapotranspiration in Panam Canal Command Using Remote Sensing and Geographical Information System (GIS)
}

\author{
Sachin Sutariya ${ }^{\text {iD }}$, Ankur Hirapara ${ }^{\text {iD }}$, Mukesh K. Tiwari* iD
}

Anand Agricultural University, College of Agricultural Engineering and Technology, Department of Irrigation and Drainage Engineering, Godhra, Gujarat, INDIA

* Corresponding author: M. K. Tiwari

* E-mail: tiwari.iitkgp@gmail.com

Received 04 Oct. 2020

Accepted 16 Dec. 2020

How to cite: Sutariya et al., (2021). Estimation of Actual Evapotranspiration in Panam Canal Command Using Remote Sensing and Geographical Information System (GIS), International Journal of Environment and Geoinformatics (IJEGEO), 8(2):193-199. doi. 10.30897/ ijegeo.820809

\begin{abstract}
Estimation of reference evapotranspiration $\left(\mathrm{ET}_{0}\right)$ and actual evapotranspiration $\left(\mathrm{ET}_{\mathrm{c}}\right)$ is a key factor for estimation of crop water requirement, water balance and irrigation scheduling. The FAO-56 Penman-Monteith equation has been accepted universally for estimating of reference evapotranspiration $\left(\mathrm{ET}_{0}\right)$. Considering the high spatial variation of meteorological phenomenon and limited availability of such dense network for data collection, application of remote sensing and GIS has gained momentum for estimation of $\mathrm{ET}_{0}$ and $\mathrm{ET}_{\mathrm{c}}$ over the larger area with accurately and efficiently. For estimation of $\mathrm{ET}_{0}$ and $\mathrm{ET}_{\mathrm{c}}$, the most widely applied MOD16 remote sensing images as well as Landsat 8 remote sensing images are applied in this study of Panam canal command area which is located in the semi-arid middle Gujarat region. Initially, FAO-56 PM method is used to estimate $\mathrm{ET}_{0}$ and MOD16 data is used to estimate $\mathrm{ET}_{0}$, whereas Landsat 8 is used to estimate land surface temperature and then by using the regression equation to estimate maximum and minimum temperature to find out $\mathrm{ET}_{0}$ for the study area. Based on result obtained, it was found that Landsat 8 remote sensing-based data have better capacity to estimate actual evapotranspiration compared to the MOD16 remote sensing data. The better performance of Landsat 8 data compared to MOD16 data is due to the reason that it has better spatial resolution(30m) compared to MOD16 $(1 \mathrm{~km})$ remote sensing image and can represent the actual field conditions of farm fields which are generally smaller.
\end{abstract}

Keywords: Reference Evapotranspiration, Actual Evapotranspiration, Crop Evapotranspiration, MOD16, LANDSAT-8, PCC

\section{Introduction}

Evapotranspiration is very important for hydrologic cycle because it represents a considerable amount of moisture lost from a plant canopy (Kumar, et al., 2012). It helps to know about climate change, land use, water budget and irrigation (Sharma Tare, 2018). Evapotranspiration is the integrated process of evaporation and transpiration and is affected by meteorological variables, crop characteristics, and management practices, as well as environmental characteristics (Pandey, et al., 2016). Study of evapotranspiration is very much important for irrigation scheduling of crops, water resources planning etc. The reference evapotranspiration multiply with crop coefficient value give the actual crop evapotranspiration rate and this can be used for irrigation scheduling (Arunadevi et al., 2017). There are many methods available to calculate reference evapotranspiration. The FAO-56 Penman-Monteith method is the standard method for computation of the reference evapotranspiration and it requires weather parameters like radiation, air temperature, air humidity and wind speed data (Hargreaves, 1994; Burak et al., 2004).

Estimation of evapotranspiration by remote sensing became popular in recent years since it is less expensive than using ground measurement (Sharma, et al., 2018). Therefore, remote sensing based MOD16 and LANDSAT-8 data have been used for this study. Moderate Resolution Imaging Spectroradiometer (MODIS) ET (MOD16) and global land ET have been produced at the global scale based on the PenmanMonteith equation. These ET products provide important information on global terrestrial water and energy cycles and environmental changes (Xiong, et al., 2015). LANDSAT - 8 is the latest satellite from LANDSAT series, it has given lot of possibilities to study the land processes using remote sensing. In this study Land surface temperature (LST) was used to calculate the actual evapotranspiration. LST was derived from Operational Line Imager Thermal Infrared Sensor (OLI \& TIRS) satellite data of Landsat- 8 because LST is sensitive to local moisture variations (Semmens et al., 2016). For estimation of ET0 Hargreaves method was applied that requires minimum and maximum temperature that was derived using a linear regression equation fitted between Land surface temperature and recorded maximum and minimum temperature in Panam weather station, Gujarat, India. Using this relationship to estimate the ET0 and crop coefficient the actual evapotranspiration was estimated. In the present study, an attempt was made to estimate reference evapotranspiration, actual evapotranspiration using field- 
based FAO-56 PM method and remote sensing based MOD16 and LANDSAT 8 methods and their performance comparison.

\section{Materials and Methods Data Collection}

The data of pan evaporation, air temperature (maximum and minimum), relative humidity (maximum and minimum), wind speed, rainfall and sunshine hours were collected from Panam Dam Circle Office Godhra, Gujarat, India for a period of two years (January-2018 to Sepetember-2019) and were applied in this study, whereas the remote sensing data of MOD16 and LANDSAT-8 were downloaded from USGS (United States Geological Survey) official website.

\section{Study Area}

The study area of the Panam Canal Command (Shown in Figure 1) which comes under the periphery of Panchmahal district, lies between latitude $22^{\circ} 27^{\prime}$ to $22^{\circ} 48^{\prime} \mathrm{N}$ and longitude $73^{\circ} 24^{\prime}$ to $73^{\circ} 32^{\prime} \mathrm{E}$. It has a total length of canal about $99.73 \mathrm{~km}$ and a cultural command area of about 36405 ha.

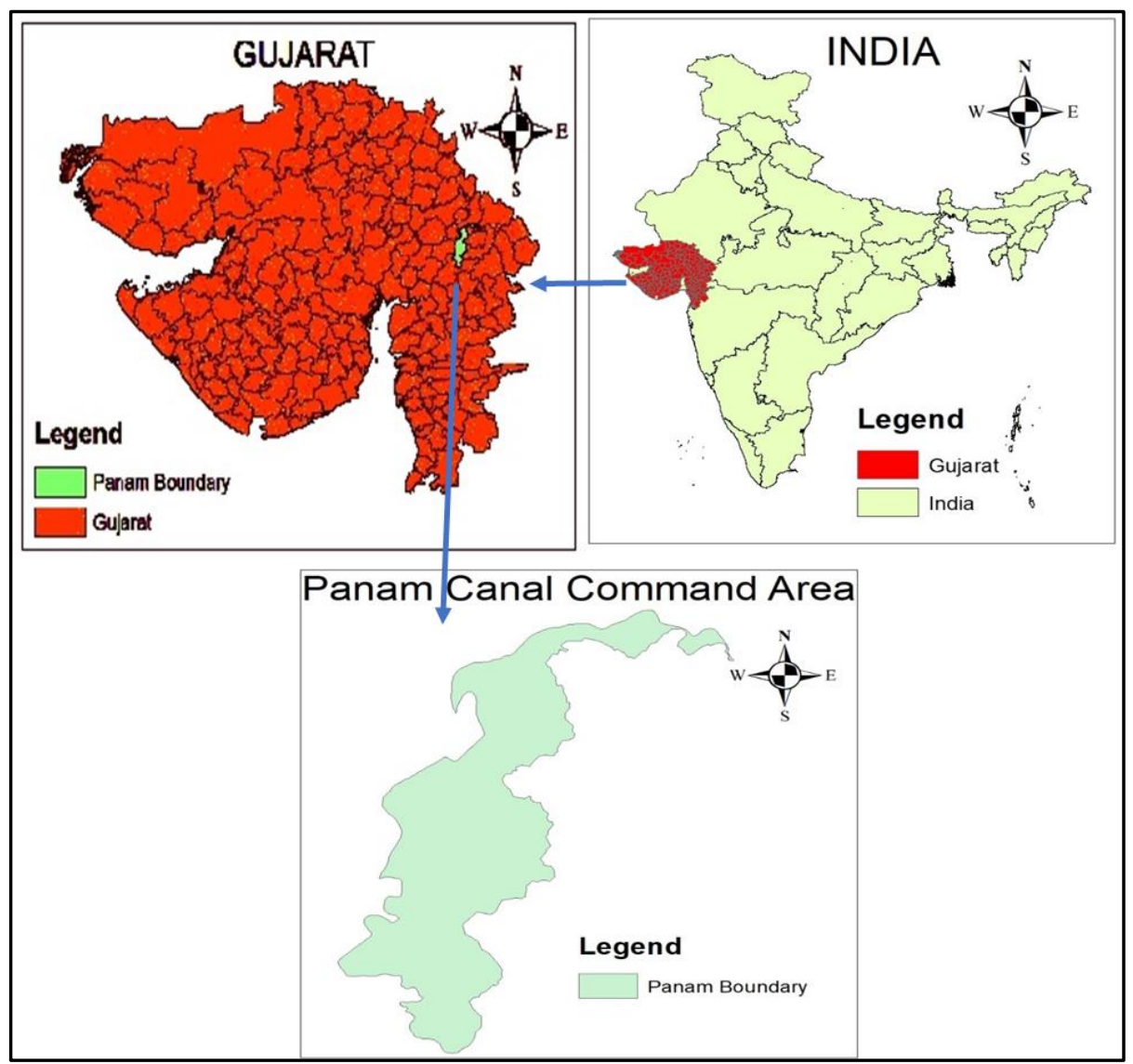

Figure 1. Location Map of Study Area.

Table.1: Stage wise crop duration and crop coefficient for the selected crops in Panam canal command

\begin{tabular}{|c|c|c|c|c|}
\hline Sr. No. & Crop & Stages & Duration (Days) & Crop Coefficient \\
\hline \multirow{3}{*}{1} & \multirow{3}{*}{ Maize } & Initial & 1 To 20 & 0.3 \\
\hline & & Mid & 21 Tо 90 & 1.08 \\
\hline & & End & 91 To 120 & 0.23 \\
\hline \multirow{3}{*}{2} & \multirow{3}{*}{ Sugar Cane } & Initial & 1 To 50 & 0.4 \\
\hline & & Mid & 51 To 210 & 1.25 \\
\hline & & End & 211 To 365 & 0.75 \\
\hline \multirow{3}{*}{3} & \multirow{3}{*}{ Paddy } & Initial & 1 To 30 & 1.05 \\
\hline & & Mid & 31 То 100 & 1.2 \\
\hline & & End & 101 To 150 & 0.9 \\
\hline \multirow{3}{*}{4} & \multirow{3}{*}{ Caster } & Initial & 1 To 30 & 0.35 \\
\hline & & Mid & 31 To 100 & 1.15 \\
\hline & & End & 101 То 150 & 0.55 \\
\hline
\end{tabular}


Methodology

Estimation of reference evapotranspiration

The FAO-56 Penman-Monteith equation being used for estimating the reference evapotranspiration is given as (Allen, et al., 1998).

$$
E T_{0}=\frac{0.408 \Delta\left(R_{n}-G\right)+\gamma \frac{900}{T_{a}+273} u_{2}\left(e_{s}-e_{a}\right)}{\Delta+\gamma\left(1+0.34 u_{2}\right)}
$$

Where, $\mathrm{ET}_{0}=$ Reference evapotranspiration in $\mathrm{mm} /$ day, $\Delta=$ Slope vapour pressure curve in $\mathrm{kPa} /{ }^{\circ} \mathrm{C}, \mathrm{R}_{\mathrm{n}}=$ Net radiation at crop surface in $\mathrm{MJ} / \mathrm{m}^{2}$ day, $\mathrm{G}=$ Soil heat flux density in $\mathrm{MJ} / \mathrm{m}^{2}$ day, $\gamma=$ Psychometric constant in $\mathrm{kPa} /{ }^{\circ} \mathrm{C}, \mathrm{T}_{\mathrm{a}}=$ Mean air temperature in ${ }^{\circ} \mathrm{C}, \mathrm{u}_{2}=$ Wind speed at $3 \mathrm{~m}$ height in $\mathrm{m} / \mathrm{sec}, \mathrm{e}_{\mathrm{s}}=$ Saturation vapour pressure in $\mathrm{kPa}, \mathrm{e}_{\mathrm{a}}=$ Actual vapour pressure in $\mathrm{kPa}$. The $\mathrm{ET}_{0}$ was estimated for the period of $1^{\text {st }}$ January-2018 to $30^{\text {th }}$ Sepetember-2019 using the equation 1.

\section{Estimation of Actual evapotranspiration using Crop Coefficient and reference Evapotranspiration}

In this study a total of 13 Farmers with 26 defined point distributed at different locations in the Panam canal command were selected as presented in Figure 2 to estimate the crop coefficient and then to estimate actual evapotranspiration. Initially, based on the crop length the crop coefficients are identified for the selected farmer's field and then actual crop evapotranspiration was estimated using ET0.

As the crop coefficient $(\mathrm{Kc})$ value is influenced by weather parameters and crop growth stages, its value differs not only from stage to stage but also varied with crops. In generally, for middle Gujarat area the crop duration and crop coefficient of different crops for their different stages are given by (Mehta et al. 2016; 2021) and for the selected crops in this study area are presented below in Table 1

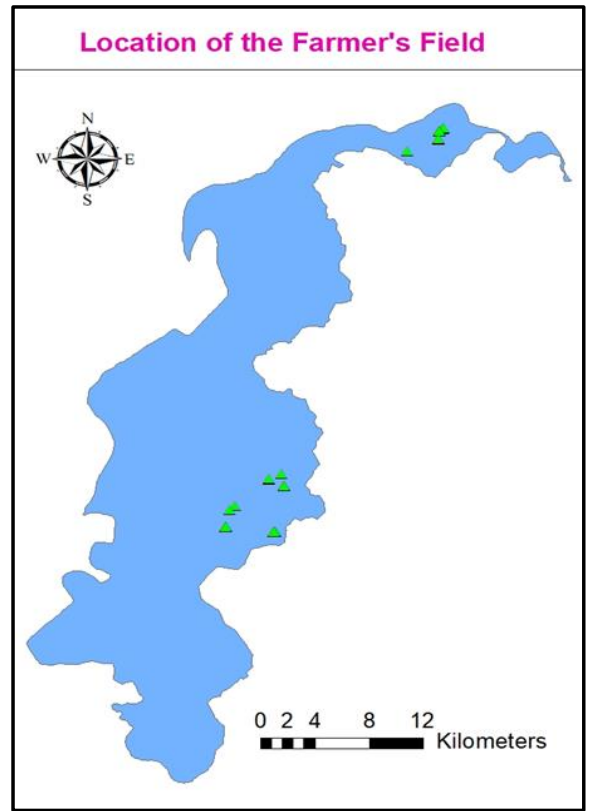

Figure 2: Location of the Selected Farmer's Field.
According to the crop coefficient and reference evapotranspiration, actual evapotranspiration for duration from October 2018 to February 2019 at defined location point in Panam canal command area was estimated using the following equation.

$\mathbf{E T}_{\mathrm{c}}=\mathbf{K}_{\mathrm{c}} \times \mathbf{E T}_{\mathbf{0}}$

Where, $\mathrm{ET}_{\mathrm{c}}$ is crop evapotranspiration, $\mathrm{K}_{\mathrm{c}}$ is crop coefficient and $\mathrm{ET}_{0}$ is reference evapotranspiration.

\section{Estimation of actual evapotranspiration based on MODIS data}

Based on the MODIS sinusoidal grid select grid of our area of interest, here Gujarat region is falls under the horizontal 24 and vertical tile number 6 , based on that select grid h24v6 for study area. These types all required MOD16A2.006 images were downloaded from official website of USGS. In these images MOD16 ET algorithm was used and it is based on the Penman-Monteith equation. The MODIS global ET algorithm is a part of NASA's Earth observing system for estimating ET from Earth's land surface using MODIS remote sensing data(Running, et al., 2019).

$\boldsymbol{E T}=\frac{\Delta\left(R_{n}-\mathrm{G}\right)+\rho_{a} C_{p} \frac{\left(r_{s}-\rho_{a}\right)}{r_{a}}}{\Delta+\gamma\left(1+\frac{r_{s}}{r_{a}}\right)}$

Where, ET = Daily evapotranspiration $\left(\mathrm{mm} \mathrm{d}^{-1}\right), \Delta=$ Gradient of saturated vapour pressure to air temperature $\left(\mathrm{Pa} \mathrm{K} \mathrm{K}^{-1}\right), \mathrm{R}_{\mathrm{n}}=$ Net radiation $\left(\mathrm{J} \mathrm{d}^{-1}\right), \mathrm{G}=$ Soil heat flux $(\mathrm{J}$ $\left.\mathrm{d}^{-1}\right), \rho_{a}=$ Air density $\left(\mathrm{kg} \mathrm{m}^{-3}\right), \mathrm{C}_{\mathrm{p}}=$ Specific heat of air at constant pressure $\left(\mathrm{J} \mathrm{kg}^{-1} \mathrm{~K}^{-1}\right), \mathrm{e}_{\mathrm{s}}$ and $\mathrm{e}_{\mathrm{a}}=$ Saturated vapour pressure and actual vapour pressure respectively $\left(\mathrm{P}_{\mathrm{a}}\right), \gamma=$ Psychometric constant $\left(0.066 \mathrm{kPaK}^{-1}\right), \mathrm{r}_{\mathrm{s}}$ and $\mathrm{r}_{\mathrm{a}}$ $\left(\mathrm{s} \mathrm{m}^{-1}\right)=$ surface and aero dynamic resistance.

\section{Estimation of actual evapotranspiration based on LANDSAT-8 data}

The remote sensing data of LANDSAT-8 were downloaded from USGS (United States Geological Survey) official website. It includes the nine shortwave bands and two longwave thermal bands. For the estimation of actual evapotranspiration, using the Thermal infrared (Band 10), near infrared (Band 5) and red (Band 4) of LANDSAT-8 land surface temperature (LST) was calculate using the following equation for the study area.

$$
T_{s}=\frac{B T}{\left\{1+\left[\frac{\lambda B T}{\rho}\right] \ln \varepsilon_{\lambda}\right\}}
$$

Where, $\mathrm{T}_{\mathrm{s}}$ is land surface temperature $\left({ }^{\circ} \mathrm{C}\right)$, BT is brightness temperature, $\varepsilon_{\lambda}$ is land Surface Emissivity, $\lambda$ limiting wave length $(10.895)$, and $\rho$ is $1.438 \times 10^{-2}$.

Land surface temperature (LST) for the Panam weather station is modelled to simulate maximum and minimum temperature by using linear regression equation. A linear 
regression equation is fitted between Land surface temperature and maximum and minimum temperature in Panam weather station. Using this relationship between the LST and maximum and minimum temperature Figure 3 of Panam weather station the reference

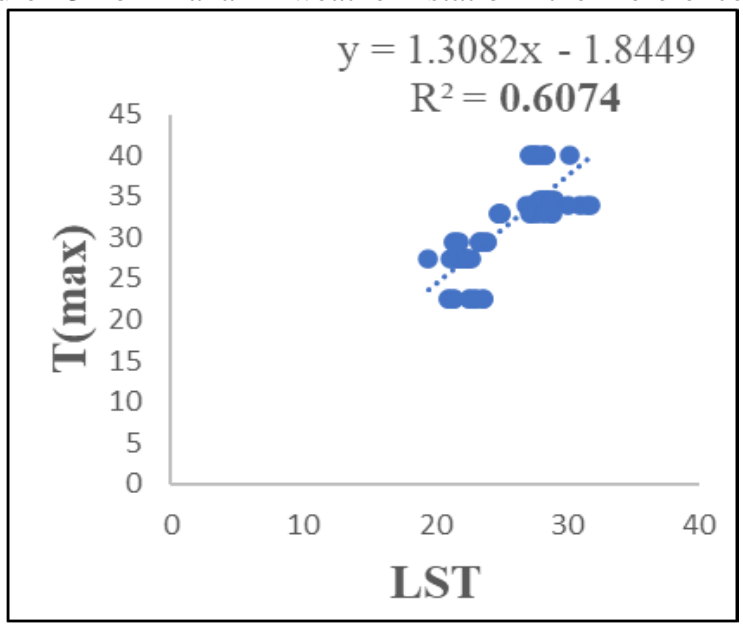

Figure 3: Relationship between the LST and maximum minimum temperature of Panam Weather Station

\section{Results and Discussion}

\section{Estimation of Reference Evapotranspiration Using the} FAO-56 Penman-Monteith Equation

The daily reference evapotranspiration $\left(\mathrm{ET}_{0}\right)$ for the year 2018 and year 2019 calculated using the FAO-56 PM methods is presented in Figure 4. It can be observed from the Figure 4 that the $\mathrm{ET}_{0}$ for the year 2018 is varying from a minimum of 0.571 to a maximum value of $7.876 \mathrm{~mm}$ /day in the month of August (29 August) and June (15 June), respectively. Similarly, in year 2019 daily reference evapotranspiration $\left(\mathrm{ET}_{0}\right)$ was varying from a minimum of 0.547 to a maximum value of 6.807 $\mathrm{mm} /$ day in the months of September (23 Sep) and June (11 June), respectively.

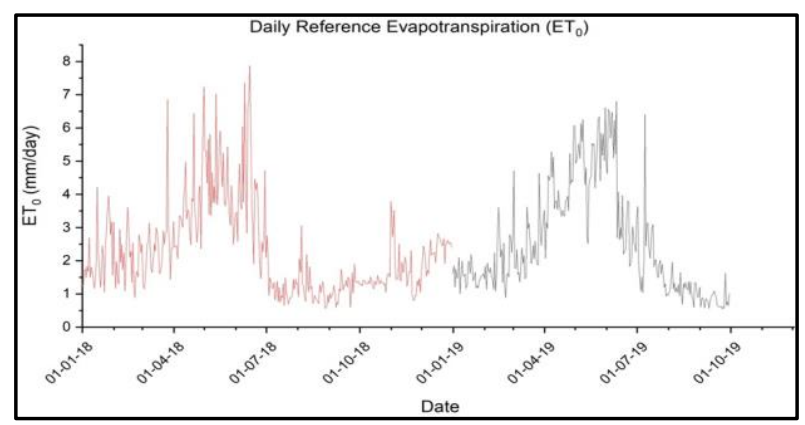

Figure 4: Daily reference transpiration $\left(\mathrm{ET}_{0}\right)$ for the year 2018 and 2019.

\section{Estimation of Actual Evapotranspiration Using the satellite based MOD16 data}

As the result for the estimation of ET using the MOD16 image considering the capability to produce the results for each $1 \mathrm{~km} \times 1 \mathrm{~km}$ grid. The MOD16 were applied to access the temporal and spatial variation of the monthly ET over the Panam canal command area. Average daily temporal and spatial variation over the Panam canal command was estimated using the MOD16 data for the October-2018 to February-2019. MOD16 gives 8-day evapotranspiration data. This image processing is done using the ArcGIS 10.0 evapotranspiration $\left(\mathrm{ET}_{0}\right)$ is estimated for the period of October-2018 to February-2019. After that the product of crop coefficient and reference evapotranspiration gives the actual evapotranspiration.

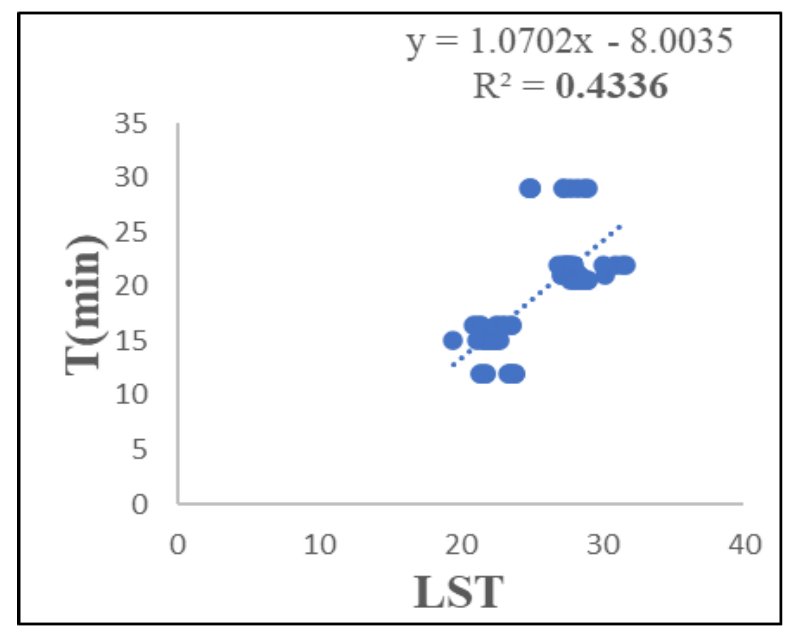

The daily evapotranspiration was estimated using FAO56 method PM method for daily basis and then it was also averaged to present the average monthly $\mathrm{ET}_{0}$. The mean monthly $\mathrm{ET}_{0}$ estimated from FAO-56 PM method is plotted for the year 2018 and 2019 in the Figure 5. It can be observed from the Figure 5 that in the year 2018, monthly mean $\mathrm{ET}_{0}$ is varying from a minimum of 1.17 $\mathrm{mm}$ /day to a maximum value of $4.46 \mathrm{~mm}$, in the months of September and May, respectively. It can also be observed from the Figure 5 that in the year 2019, monthly mean $\mathrm{ET}_{0}$ is varying from a minimum of 0.80 $\mathrm{mm}$ /day to a maximum value of $5.13 \mathrm{~mm}$ /day in the months of September and May, respectively.

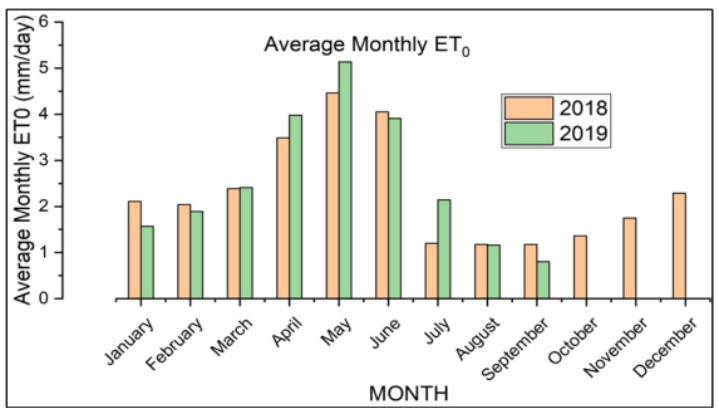

Figure 5: Mean monthly reference evapotranspiration of year 2018 and 2019.

and ERDAS IMAGINE 11.0 software. After that multiply with 0.1 over defined location point value and get the actual ET value in $\mathrm{mm} /$ day or $\mathrm{mm} / 8$-day. The average daily ET for the duration from October-2018 to February-2019 is presented in Figure 6. Now, for the selected farmer's fields the actual $\mathrm{ET}_{0}$ estimated from the MOD16 data are extracted for the selected duration considering the availability of remote sensing data for both the satellites of MOD16 and Landsat 8. ETc extracted from the MOD16 data for the selected farmer's fields is presented in Figure 7. 


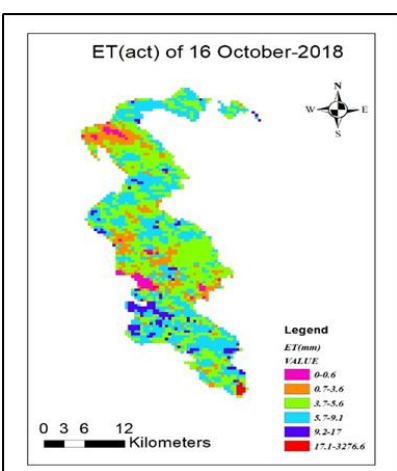

(a) $16^{\text {th }}$ Oct 2018

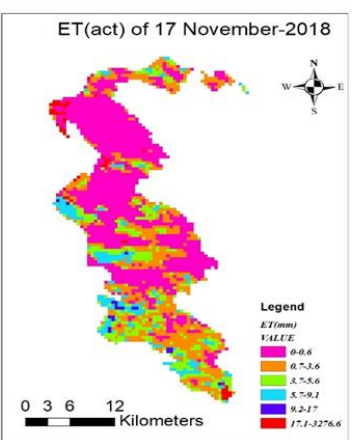

(c) $17^{\text {th }}$ Nov. 2018

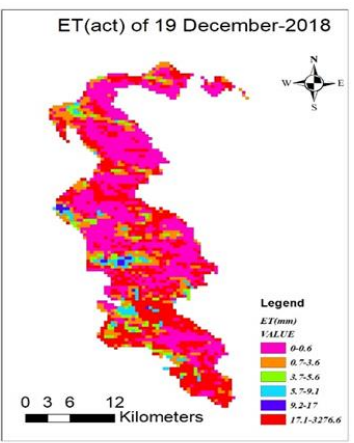

(e) $19^{\text {th }}$ Dec. 2018

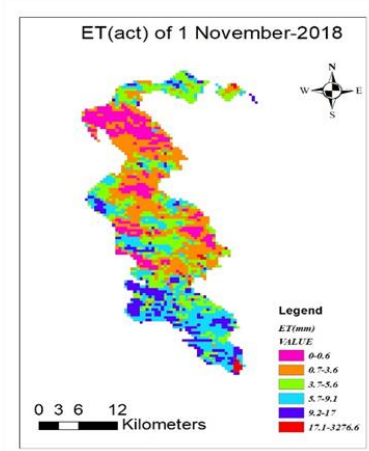

(b) $1^{\text {st }}$ Nov. 2018

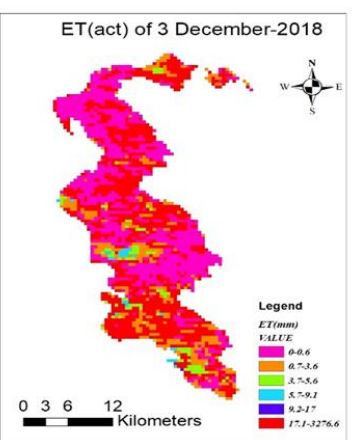

(d) $3^{\text {rd }}$ Dec. 2018

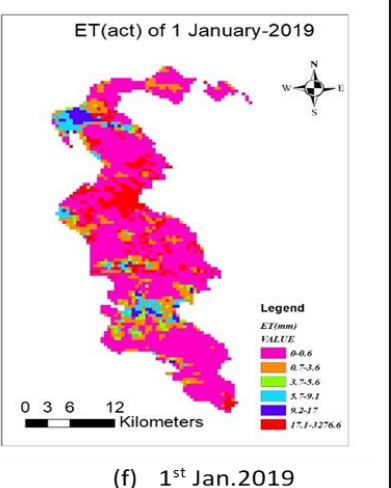

Figure 6: Average daily ET for the duration from October-2018 to February-2019

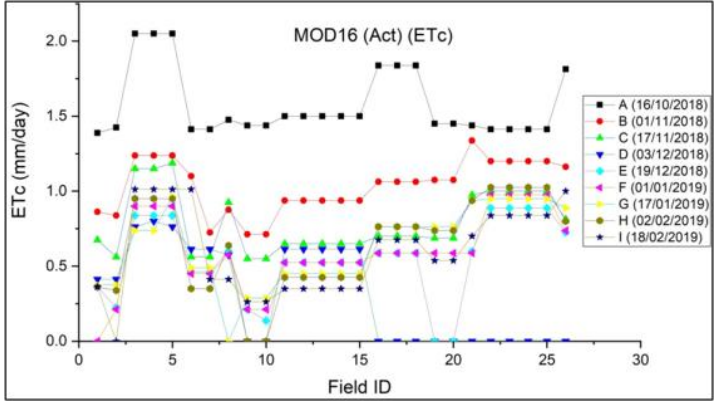

Figure 7: MOD16 Actual ET of defined location point

\section{Estimation of Actual Evapotranspiration Using the} satellite-based LANDSAT-8 data

The model was created in Arc GIS for estimating land surface temperature, and it can only be used to process LANDSAT 8 data because of the data complexity. At the defined location point in to the LANDSAT-8 map, the land surface temperature was identified for duration October-2018 to February-2019 which shown in Figure 8. Land surface temperature of temporal and spatial variation over the Panam canal command was estimated using the LANDSAT- 8 data for the month

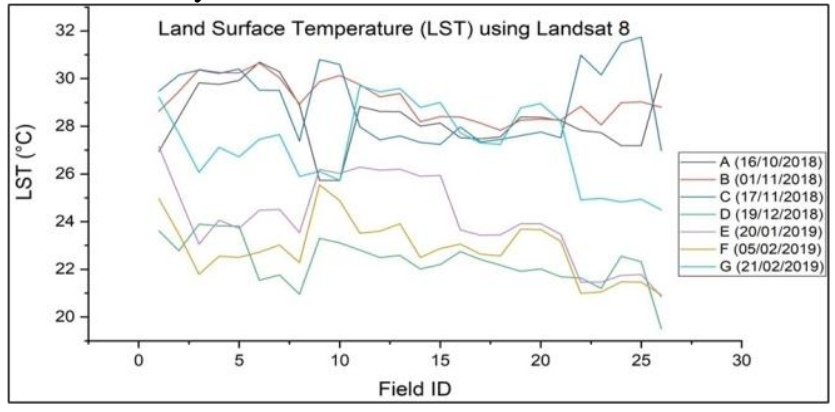

Figure 8: LANDSAT-8 land surface temperature of defined location point.

October-2018 to February-2019 which shown in Figure 9. Using the relationship between the LST and maximum and minimum temperature of panam weather station the reference evapotranspiration $\left(\mathrm{ET}_{0}\right)$ is estimated for the period of October-2018 to February-2019 is shown in Figure 10. The actual evapotranspiration is estimated by using LANDSAT-8 reference evapotranspiration and correlated crop coefficient for defined location point of different field crop is shown in Figure 11. 


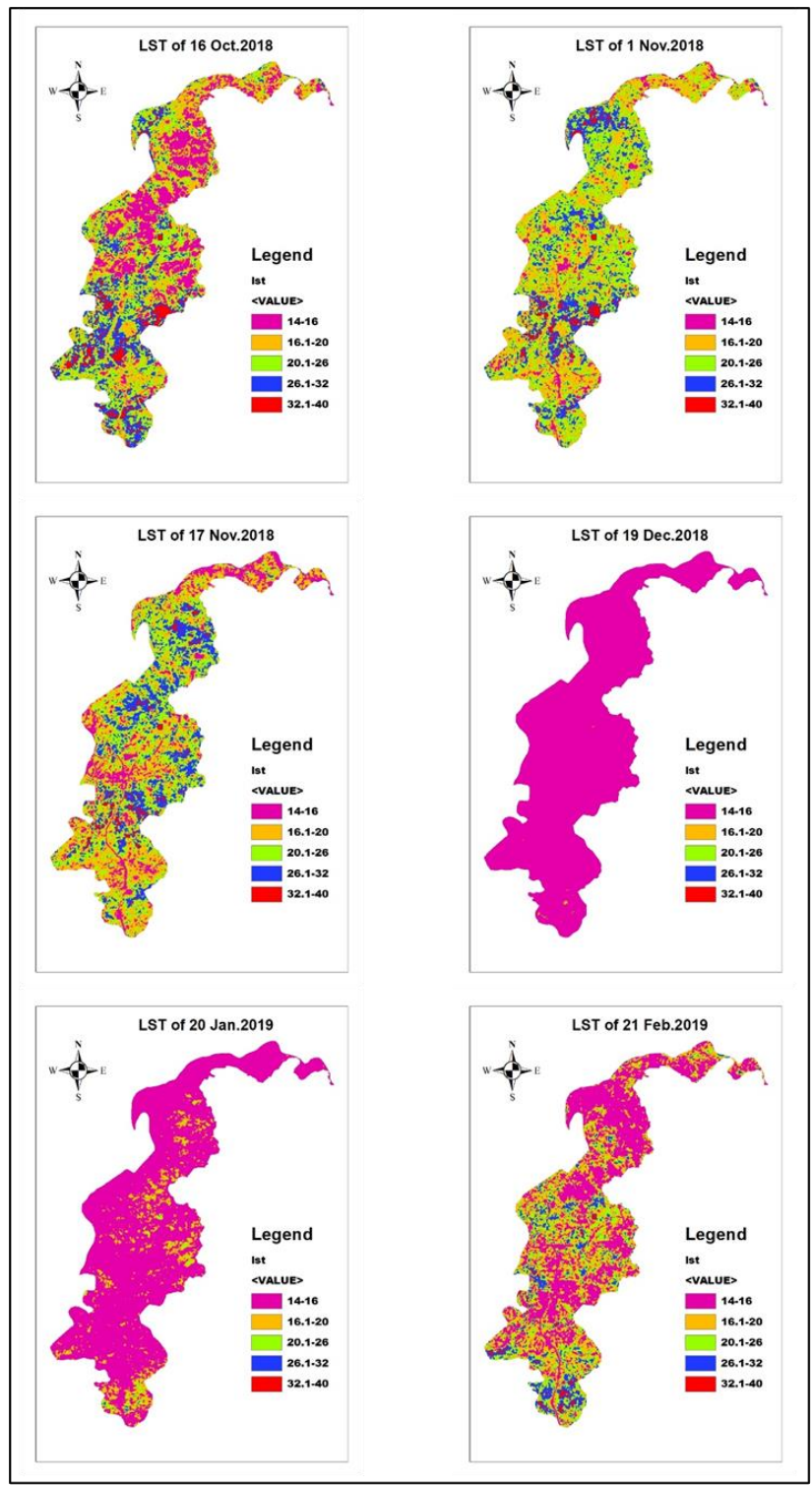

Figure 9: LST for the duration from October-2018 to February-2019.

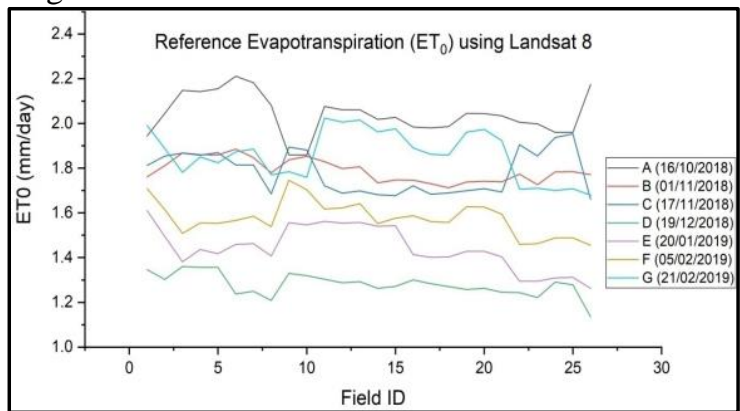

Figure 10: LANDSAT-8 Reference evapotranspiration of defined location point.

Comparison of actual evapotranspiration using the satellite based MOD16 and LANDSAT-8 data and field data for different crops in Panam canal command area Scatter plot between the MOD16 and field based $\mathrm{ET}_{0}$ is presented in Figure 12 It can be observed from the graph that the MOD16 based ETc values are not in accordance

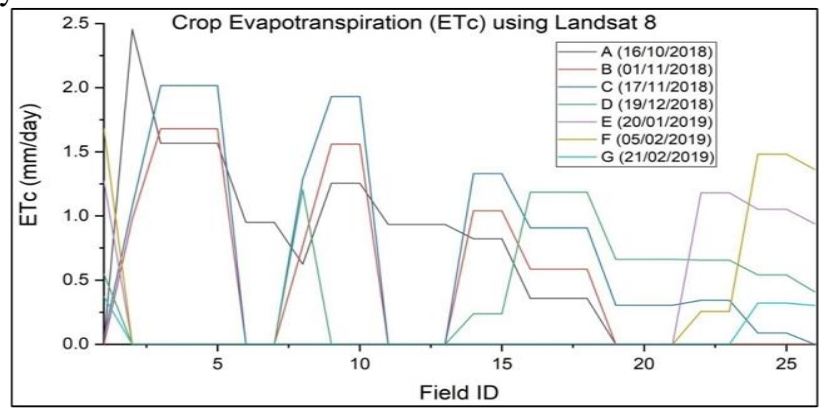

Figure 11: LANDSAT-8 Actual evapotranspiration of defined location point of different field crop

with the field based $\mathrm{ET}_{\mathrm{c}}$ for the selected fields. Scatter plot between the Landsat based and field based $\mathrm{ET}_{\mathrm{c}}$ is presented in Figure 13. It can be observed from the graph that the Landsat 8 based $\mathrm{ET}_{\mathrm{c}}$ values are showing the general behaviour as that of the field based $\mathrm{ET}_{\mathrm{c}}$ for the selected fields. 


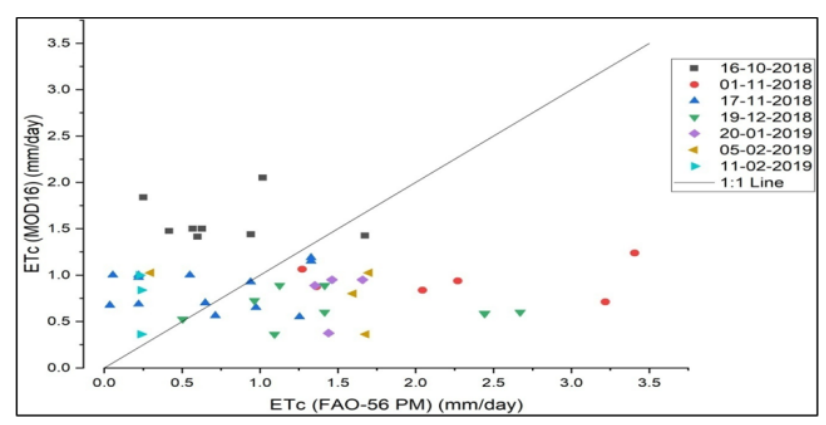

Figure 12: Comparison of $\mathrm{ET}_{\mathrm{c}}$ estimated using field-based FAO-56 PM method and MOD16 based method.

\section{Conclusions}

Applying the filed climatological data for the Panam canal command reference $\mathrm{ET}_{0}$ is estimated using the FAO-56 PM method for the year 2018 and year 2019.The highest $\mathrm{ET}_{0}$ was observed in the month of May (138.25 in year 2018 and 159.11 in the year 2019) and the minimum $\mathrm{ET}_{0}$ was found in the month of September (35.22 in the year 2018 and 24.09 in the year 2019). Based on result obtained, it was found in this study that Landsat 8 remote sensing-based data have better capacity to estimate $\mathrm{ET}_{0}$ compared to the MOD16 remote sensing data. The better performance of Landsat 8 data compared to MOD16 data is due to the reason that it has better spatial resolution $(30 \mathrm{~m})$ compared to MOD16 $(1 \mathrm{~km})$ remote sensing image and can represent the actual field conditions of farm fields which are generally smaller. Therefore, in the reason where availability of actual climatological data is limited, use of Landsat 8 based $\mathrm{ET}_{0}$ can be recommended.

\section{References}

Allen, R. G., Pereira, L. S., Raes, D., Smith, M., Ab, W. (1998). Fao,1998. Irrigation and Drainage Paper No. 56, FAO, 300. doi.org/10.1016/j.eja.2010.12.001.

Arunadevi K, Ramachandran J, Vignesh S, Visuvanathakumar S, Anupriyanka S. (2017). Comparison of Reference Evapotranspiration in Semi-Arid Region. International Journal of Agriculture Sciences Citation, 9(52), 4886-4888.

Burak, S., Doğan,E., Gazioğlu, C. (2004). Impact of urbanization and tourism on coastal environment, Ocean Coast Manag.,47. 515-527, 10.1016/j.ocecoaman. 2004.07.007

Hargreaves, B. G. H. (1994). REFERENCE EVAPOTRANSPIRATION By George H. Hargreaves, 1 Fellow, ASCE. Journal of Irrigation and Drainage Engineering, 120(6), 1132-1139.

Kumar, R., Jat, M. K., Shankar, V. (2012). Methods to estimate irrigated reference crop evapotranspiration A review. Water Science and Technology, 66(3), 525-535. doi.org/10.2166/wst.2012.191.

Mehta, D., Shukla, S., Kalubarme, M. (2021). Winter Crop Growth Monitoring using Multi-Temporal NDVI Profiles in Kapadvanj Taluka, Gujarat State., International Journal of Environment and

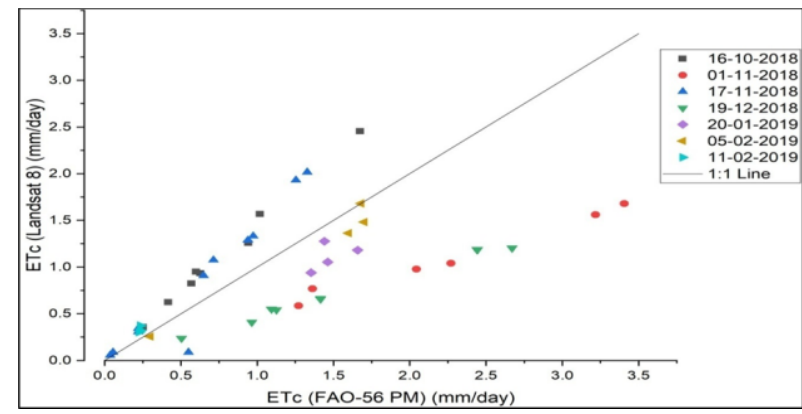

Figure 13: Comparison of $\mathrm{ET}_{\mathrm{c}}$ estimated using field-based FAO-56 PM method and Landsat 8 based method.

Geoinformatics, 8(1), 33-38.doi 10.30897/ijegeo. 773860.

Mehta, R., Pandey, V., Lunagaria, M. M., Kumar, A. (2016). Reference and crop evapotranspiration estimation for mustard reference and crop evapotranspiration estimation for mustard and chickpea at different locations of. (January).

Pandey, P. K., Dabral, P. P., Pandey, V. (2016). Evaluation of reference evapotranspiration methods for the northeastern region of India. International Soil and Water Conservation Research, 4(1), 52-63. doi.org/10.1016/j.iswcr.2016.02.003.

Running, S. W., Mu, Q., Zhao, M., Moreno, A. (2019). User's Guide MODIS Global Terrestrial Evapotranspiration (ET) Product (MOD16A2/A3 and Year-end Gap-filled MOD16A2GF/A3GF) NASA Earth Observing System MODIS Land Algorithm

Semmens, K. A., Anderson, M. C., Kustas, W. P., Gao, F., Al, J. G., Mckee, L., ... Vélez, M. (2016). Remote Sensing of Environment Monitoring daily evapotranspiration over two California vineyards using Landsat 8 in a multi-sensor data fusion approach. 185, 155-170. doi.org/10.1016/ j.rse.2015.10.025

Sharma, D. N., Tare, V. (2018). Evapotranspiratio estimation using ssebop method with sentinel-2 and landsat-8 data set. ISPRS - International Archives of the Photogrammetry, Remote Sensing and Spatial Information Sciences, XLII-5(November), 563-566. doi.org/10.5194/isprs-archives-xlii-5-563-2018

Xiong, Y. J., Zhao, S. H., Tian, F., Qiu, G. Y. (2015). An evapotranspiration product for arid regions based on the three-temperature model and thermal remote sensing. Journal of Hydrology, 530, 392-404. doi.org/10.1016/j.jhydrol.2015.09.050 